УДК 82I.I6I.I.0

ББК $83.3(2 \mathrm{Poc}=\mathrm{Pyc}) \mathrm{I}$
ПОВЕСТЬ О ЧУДОТВОРНОЙ

КАЗАНСКОЙ ИКОНЕ БОГОМАТЕРИ

В СВЕТЕ ДРЕВНЕРУССКОЙ ЛИТЕРАТУРНОЙ ТРАДИЦИИ

(C) 2017 г. В.М. Кириллин

Институт мировой литературы им. А.М. Горького

Российской академии наук, Москва, Россия

Дата поступления статьи: 03 января 2017 г.

Дата публикации: 25 марта 2017 г.

DOI: IO.22455/25OO-4247-20I7-2-I-I5O-I83

Аннотация: «Повесть о Казанском чудотворном образе Богоматери» относится к ряду других древнерусских сказаний о явлении или обретении богородичных икон. В статье в сопоставлении со сказаниями о Колочской, Тихвинской, Оковецкой и Выдропусской иконах рассматривается структура сюжетных мотивов, организующих нарративную часть повести, выявляется комплекс традиционных и новых особенностей построения данного текста и его художественная специфика, обусловленная как общим ходом развития русской литературы в конце XVI в., так и общественной ситуацией в недавно присоединенной к Московскому государству Казани и официальным положением митрополита Казанского Гермогена, наиболее вероятного автора повести. Сравнение текстов указанных памятников позволяет выявить типичность и каноничность сюжета, композиции и языка повести о Казанской иконе, несмотря на наличие в ней новых повествовательных мотивов и авторской рефлексии. Автор повести твердо держался официальной идейно-эстетической традиции и литературной нормы, руководствуясь официальными церковно-политическими и духовными представлениями, лишенными тенденций к описательным преувеличениям на почве живого воображения, религиозной экзальтации, мистицизма. Сюжетно-стилистическая нормативность сочинения Анонима-Гермогена контрастно оттеняется преданиями о Колочской, Оковецкой и отчасти Выдропусской иконах Пресвятой Богородицы, облеченными в форму драматургически организованного и стилистически близкого к живой русской речи нарратива. Это дает основания для определенных выводов относительно особенностей исторического развития русской литературы в Московской Руси второй половины XVI в., когда в официальном русле ее развития шел известный процесс консервации и формализации литературной работы.

Ключевые слова: повесть, сказание, сюжет, мотив, повествовательная деталь, литературная традиция, канон, жанровая природа, сравнение, мариология.

Информация об авторе: Владимир Михайлович Кириллин - доктор филологических наук, ведущий научный сотрудник, Институт мировой литературы им. А.М. Горького Российской академии наук, ул. Поварская, д. 25 а, І2Іо69 Москва, Россия.

E-mail: kvladimirm@mail.ru 


\section{"THE TALE OF THE MIRACULOUS ICON OF OUR LADY OF KAZAN" IN THE LIGHT OF OLD RUSSIAN LITERARY TRADITION}

This is an open access article distributed under the Creative Commons Attribution 4.0 International (CC BY 4.0)
(C) 20I7. V.M. Kirillin

A.M. Gorky Institute of World Literature of Russian Academy of Sciences Moscow, Russia

Received: January 03, 2017

Date of publication: March 25, 2017

Abstract: "The Tale of the Miraculous Image of Our Lady of Kazan" is related to other Old Russian tales with the motif of apparition or discovery of the icon of Our Lady. Reading this tale in comparison with the tales of Kolochskaya, Tikhvin, Okovetskaya, and Vydropusskaya icons, I will focus on the structure of its plot motifs that organize the tale's narrative. The essay reveals a combination of traditional and novel features in the construction of the text and the specificity of the story. The latter was determined by some general trends in the development of Russian literature at the end of the $16^{\text {th }}$ century as well as by the social circumstances in the newly added Kazan State and by the official position of the Kazan Metropolitan Hermogenes, a presumed author of the tale. A comparative reading reveals typicality and conventionality as regards the plot, the structure, and the language of the tale about the Kazan icon, despite the presence of new motifs and elements of authorial selfreflection. The author of the tale rigorously followed official ideological and aesthetic line as well as existing literary standards and was guided by the mainstream clerical, political, and spiritual ideas that did not favor descriptive exaggerations inspired by imagination, religious exaltation, and mysticism. There is a stark contrast between the conventional tale by Anonymous-Hermogenes and legends about Kolochskaya, Okovetskay, and (to some extent) Vydropusskaya icons of the Holy Virgin that represent narratives dramatically and stylistically close to the folk speech. Such reading gives grounds to certain conclusions about the peculiarities of the historical development of Russian literature in Moscow Rus' of the second half of the $16^{\text {th }}$ century. The official line of its development was primarily aimed at the conservation and formalization of creative work.

Keywords: story, legend, plot, motive, narrative detail, literary tradition, canon, genre nature, comparison, mariology.

Information about the author: Vladimir M. Kirillin, DSc in Philology, Leading Research Fellow, Professor, A. M. Gorky Institute of World Literature of the Russian Academy of Sciences, Povarskaya 25 a, I2I069 Moscow, Russia.

E-mail: kvladimirm@mail.ru 
Казанский образ Пресвятой Богородицы, несомненно, должно считать одной из самых чтимых в Русской Православной Церкви чудотворных икон [46; 47]. Ко времени его прославления через чудесное обретение в I579 г. в Московской Руси почиталось уже немало подобных святынь ${ }^{\mathrm{I}}$. Соответственно, русская средневековая письменность сохранила несколько сюжетно развитых и весьма популярных сказаний, наряду, между прочим, со множеством предельно простых и кратких по содержанию летописных упоминаний о разных чудесных знамениях, связанных с богородичными иконами [I7, с. 207-21о]. Собственно «Повесть о Казанском чудотворном образе Богоматери», о которой далее пойдет речь, была написана в 1594 г. Ее составителем считается непосредственный свидетель этого чуда митрополит Казанский Гермоген, впоследствии патриарх всея Руси и священномученик ${ }^{2}$.

Как уже отмечено, в жанровом отношении повесть пополняет собою ряд древнерусских переводных и оригинальных текстов, описывающих истории чудотворных икон. В XII в. появляется первый свод литературных свидетельств о Владимирском образе Богородицы, а к середине XVI в. на его основе сформировался уже весьма обширный текст, обобщающий все имеющиеся на тот момент предания о святыне [49, s. І39-I59; 11]. В XIV-XV вв. складывается цикл текстов, посвященный новгородской чтимой иконе «Знамение» [49, s. I33-I39; 2; 3; 4]. В конце XIV в. в круг русского чтения попадает

I Множество месяцесловных общерусских и местных памятей, посвященных богородичным чудотворным иконам не раз отмечалось [29, с. 40].

2 «Мъсяца Июля в 8 день. Повесть и чюдеса Пречистые Богородицы честнаго и славнаго Ея Явления образа иже в Казани. Списано смиренным Ермогеном митрополитом Казаньским» [4I, c. I-I6]. См. также: Повесть о явлении и чудесах Казанской иконы Богородицы $[8$, c. $24-53]$. 
в виде перевода с греческого пространный рассказ о ранних изображениях Богоматери, иконах «Лиддской» и «Римской»3. В XV в. возникает сказание о Колочской иконе [49, s. I6о-I68]. C конца XV в. до середины XVI в. развивается основа литературного предания о Тихвинской иконе [I9]. В середине XVI в. русские читатели знакомятся со сказаниями об иконах Богородицы Оковецкой (Ржевской) [49, s. І88-г93; 32], Выдропусской [ıо; 50, s. I68-I73], Иверской $[48 ; 9 ; 49$, s. 56-6о]. Все эти тексты в той или иной редакции включались в XVI в. в обобщающие летописные своды, в частности в Никоновский и Лицевой, в Степенную книгу, в агиографические сборники, в рукописные книги смешанного содержания, т. е. были достаточно распространены. Поэтому вполне правомерно допустить, что хотя бы в каком-то виде они могли быть известны автору «Повести о Казанской иконе» и что, соответственно, последний создавал свой текст, будучи знакомым с уже твердо сложившейся традицией русской мариологической литературы, к коей относятся сказания о богородичных иконах.

Правда, нужно заметить, что указанные выше повествования отражают разные типы чудесных историй. Например, основополагающий мотив ${ }^{4}$ литературного предания о Владимирской святыне - это перенесение, о Тихвинской - явление, о Колочской - обретение, об образе «Знамение» - воинский подвиг5. Между прочим, в ходе кристаллизации сведений о той или иной иконе основные мотивы могли смешиваться. Кроме того,

3 «В понедельник вторыя недели святаго и великаго поста, сказание известно о чюдесех Пресвятыя Владычицы нашея и Госпожи Пречистыя Девы и Богородицы Марии, еже пречистою и честною Ея иконою содеяся, яже и римляныни нарицатися обыкши» [36, л. 338 об. 359 (глава 26); 50, с. 244-248]. Греческий оригинал «Сказания» [5I, s. 325-337]. Ср. с русским изданием [36].

4 В современном литературоведении под мотивом в сюжете литературного произведения понимается определенная постоянно повторяющаяся «повествовательная» или «смысловая» единица, тяготеющая к формально-содержательному усложнению за счет ее варьирующейся образной реализации, варьирующегося сюжетно-композиционного сочетания с другими подобными единицами рассказа, варьирующейся функциональной связи с действующими лицами, варьирующегося словесного выражения. Мотивы могут быть основными, второстепенными, эпизодическими, описательными, лирическими, интертекстуальными, внутритекстовыми, символическими [44].

5 Несколько иная трактовка основных мотивов сказаний об иконах предложена в работах Л.И. Журовой и А. Кризы [І6; 22]. Повествовательная специфика сказаний об иконах рассмотрена также в статье Е.Л. Конявской [20]. Однако последняя исследовательница не касается проблемы мотивов в сюжетном построении памятников данной жанровой группы, сконцентрировав свое внимание на проблеме связи традиционной литературной структуры текстов с отразившимся в них устно-легендарным преданием. 
всегда реализовывались (и тоже нередко в комбинированном виде и разнясь по сути и характеру) сопровождающие, дополняющие - описательные и пояснительные - мотивы, связанные с суммой определенных фактов свершившихся чудес (помощь в болезнях, в житейских ситуациях, при решении каких-то общественных или личных вопросов, необычные происшествия, избавление от опасности) и фактов реакции на чудесное со стороны простых участников событий и власти (вера, неверие, молитва, насмешка, вразумление, устрашение, способствование, сопротивление). Так или иначе мотивы эти сопряжены были с доминантными особенностями жизни средневекового русского общества: взаимодействием с иноземными и иноверными соседями, внутренними общественными отношениями, междоусобными распрями, преодолением «глада и мора», морально-нравственными взлетами и падениями, политическим или религиозным напряжением, возникновением храмов и монастырей. Так или иначе мотивы эти в рамках разных сюжетов всегда весьма разнообразно сочетались друг с другом, а главное, всегда воплощались в конкретных повествовательных формах со своим набором фактологических деталей и средств художественной изобразительности.

В этой связи «Повесть о Казанской иконе» выглядит как весьма типичное произведение. Причем ее типичность характеризуется, во-первых, довольно полным набором традиционных литературных мотивов, используя которые автор строит собственный рассказ, во-вторых, слабой сюжетноизобразительной разработанностью этих мотивов, в-третьих, - краткостью и трафаретностью, шаблонностью их словесной реализации в плане языка и стилистики изложения.

Что же представляет собой на фоне литературной традиции текст означенного памятника? Как ни удивительно, его развернутых научных исследований, в сущности, нет. Можно отметить только наблюдения и выводы немецкого коллеги А. Эббингхауза [49, s. 209-219] и написанную О.В. Панченко на их основе небольшую справку, предваряющую комментарии к нему в издании Библиотеки Литературы Древней Руси [8, с. 67I-673]. При этом происхождение произведения все-таки остается недостаточно ясным. Первые публикации «Повести» как сочинения святителя Гермогена [25, c. I-XIX; I] делу не помогли, тем более что академик П.М. Строев, авторитетный археограф и библиограф, по ее поводу высказался весьма опреде- 
ленно: «митрополит Гермоген не сочинил ее, а только переиначил и дополнил» [5, с. 62]. Это мнение разделил и академик А.И. Соболевский, который на основе палеографического анализа списка памятника из Синодального собрания рукописей ГИМ (Син., № 982), созданного в I594 г. тремя писцами, в том числе и святителем Гермогеном, выдвинул предположение, что первоначальный вариант произведения появился до I584 г., т.е. вскоре после чудесного обретения иконы, однако о его составе, содержании и авторе ученый совершенно умолчал [34, с. 5-7]. Кстати, ныне причастность Гермогена к работе над списком Син-982 в качестве писца и справщика убедительно доказана [13, с. 4-12, 22]. Упомянутый выше А. Эббингхаус, констатировав большую известность «Повести» среди древнерусских книжников, выявил списки (РГБ, собр. Н. С. Тихонравова № 587, собр. Н.П. Румянцева, № 36г и № 367, собр. ОИДР № 222; РГАДА, собр. МАМИД № 639; ГИМ, собр. Н.П. Вострякова № 207а), передающие текст произведения в сокращенном виде (редакция А) сравнительно с текстом Син-982 (редакция G), чаще встречающимся в рукописных копиях. По наблюдению ученого, во всех указанных списках (и, соответственно, в краткой и пространной версиях произведения) обязательно наличествует основной рассказ (разделы C и D), посвященный собственно истории обретения и прославления Казанского образа, - повествование от слов «Бысть же сице. В лето $7087 . . »^{6}$ до сообщений о начале почитания иконы после двух первых исцелений по обращенным через нее молитвам к Пресвятой Богородице, о дальнейшей судьбе тайнозрительницы Матрены и ее матери, о донесении царю, о царском распоряжении построить на месте обретения святыни Одигитриевской церкви и основать при ней девичий монастырь [4I, с. 4-9]; остальные же разделы - введение (А и В), рассказы о чудесах, случившихся уже после обретения святыни (F), свидетельства автора о собственной причастности к описанным событиям $(\mathrm{G})$, заключение $(\mathrm{H})$ - варьируются и текстуально, и по факту их наличия-отсутствия в произведении. А. Эббингхаус, кроме того, замечает, что в списках редакции А текст основного рассказа выглядит стилистически несколько проще, чем в редакции G. Правда, этот вывод подтверждается только одним примером. В итоге исследователь констатирует первичность редакции А, анонимной, по отношению к редак- 
ции $\mathrm{G}$, связанной со святителем Гермогеном. Что же касается текста разделов $\mathrm{C}$ и $\mathrm{D}$, то таковой вырос из первоначального письменного донесения царю и дополняющих его устных рассказов [49, S. 2Іо-2II, 2I3-215]. Должно, однако, добавить от себя: при создании редакции G эти два основных раздела не претерпели существенных текстуальных изменений. В целом же новая версия «Повести» (включая предисловие, основную часть, авторские отступления, рассказы о чудесах, автобиографические пассажи и заключение), несомненно, родилась как плод единовременной литературной работы, произведенной книжником, достаточно начитанным и осмысленно относящимся к своему писательскому и редакторскому делу. Наконец, нельзя не взять в соображение, что наиболее вероятный составитель версии G, святитель Гермоген, работая над ней, уже был одним из высших иерархов Русской Церкви и в силу своего официального положения должен был ориентироваться на некий литературный стандарт. Разумеется, стандарт неписаный, однако сопряженный с комплексом официальных церковно-политических, идейно-эстетических и духовных представлений, лишенных, как можно думать, тенденций к описательным преувеличениям на почве живого воображения, религиозной экзальтации, мистицизма.

По особенностям основного содержания, т. е. собственно рассказа о прославлении иконы Божией Матери в Казани, совместное произведение Анонима-Гермогена ближе всего к сказаниям о явлении или об обретении чудотворных святынь. Соответственно, целесообразнее соотносить его сюжетную структуру, в первую очередь, со сказаниями о Колочской и Тихвинской ${ }^{8}$ иконах Пресвятой Богородицы. Вместе с тем следует учитывать, что литературная история этих сказаний, возникших спустя довольно длительное время после описанных в них событий, характеризуется заметным текстуальным развитием от первоначальных вариантов к последующим, с более разработанным сюжетно-композиционным построением. Тогда как текст «Повести о Казанской иконе» был написан очевидцем чуда чуть ли не по его горячим следам и в разделах основного рассказа почти не менялся

\footnotetext{
7 «О иконе Пречистыя Богородицы, иже от Можайску на Колоче» [6, с. IоO-Іо5,

507-509 (подгот. текста, перевод и коммент. Л.И. Журовой)]. Далее текст памятника цитируется по этому изданию.

8 «Сказание о чюдесех Пречистыя Богородицы чюдотворнаго ея образа Одегитрия, како явися на Тифине...» [І9, с. 245-258 (редакция Е)]. Далее текст памятника цитируется по этому изданию.
} 
при последующем тиражировании. Похожая литературно-историческая ситуация, между прочим, отличает и сказание об Оковецком образе9.

При сопоставлении названных произведений, однако, непременно должно иметь в виду жанровые различия. Так, колочская история не является прямой историей Божественного вмешательства в жизнь людей. Это история человека, случайно нашедшего (в I4I3 г.) икону Пресвятой Богородицы, история его последующего духовного торжества, нравственного падения, физического наказания и покаянного исправления. Это прототип бытовой повести, в сюжетной структуре которой рассказ об обретении иконы выполняет функцию завязки, или экспозиции, по отношению к последующему рассказу об обретателе, причем не святом подвижнике, а личности самой обыкновенной. Бытовым характером отличается и сказание об Оковецкой святыне. История прославления этого образа (в I539 г.) связана с рассказом об обыденной жизни людей далеких от праведности: образ являет себя не по благочестию кого-либо, а как бы в укор воровству и алчности воров и любопытству праздно гуляющего народа; сначала обнаруживается прибитый к дереву немецкий крест, затем на другом дереве неподалеку и сам образ; вопреки массовым чудесам исцелений, обе святыни долго остаются в лесу; лишь после того, как об этом становится известно митрополиту Иоасафу и юному царю Ивану Васильевичу IV, их доставляют в Москву.

Отсюда следует, что только «Сказание» о Тихвинской иконе по жанровой природе наиболее близко исследуемому литературному памятнику.

Первостепенную важность, нужно думать, составляет то, как построен нарратив основной части «Повести о Казанской иконе» (разделы C и D). Начинается она, как выше отмечено, по летописному образцу - «Бысть же сице. В лето 7087...». Далее характеризуется время события, пожара в Казани, - описательно (при Иване Васильевиче Грозном, «всея Руси самодержце», при его детях Иване и Федоре, при митрополите Московском Антонии, при архиепископе Казанском Иеремии) и прямо (23 июня на память мученицы Агриппины, через 26 лет после взятия Казани, в полдень). При этом точно обозначается и место действия (в посаде, около храма Николы Тульского, во дворе царева воина Данилы Онучина). Описание пожара и его последствий дополнено пространным рассуждением на тему милосердия Бо-

9 «Сказание о явлении иконы Пречистыя Богородицы Оковецкия (Ржевския)»

[24, с. 7-15]. Далее текст памятника цитируется по этому изданию. 
жия по отношению к православным и торжества православной веры в условиях конфессиональной розни среди иноязычного и иноверного казанского населения. Это рассуждение, несомненно, придавало тексту повести идеологическое звучание:

«Людие же христолюбивии, верою не отпадше, но познаша своя согрешения, на покаяние обратишася, и начаша созидати церкви Божия и своя домы. И, Божиею милостию, место убо иноязычно и новопросвещзено просвешашеся святыми иерквами и божествеными учении.

Языцы же невернии мнози бяху во граде, и веры многи. И бысть им в притчю и в поругание истинная православная вера; источника же иелебна-

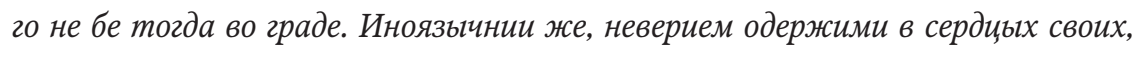
уничижаху нас, не ведяще Божия милости и силь, видеша бо, окаянии, Божие милосердие к нам - еже с милостию наказание, еже милуяй нас наказуя, яко отеи, чадолюбив, за наша согрешения, оцышая грехи наша.

Человеколюбеи, же Бог, видя терпение людей своих и веру их, и поругание и поношение окрест живущи иноверных, и не терпя поношения и похуления на святыя иконь...».

Нужно отметить, что авторское комментирующее вмешательство в изложение событий в сказаниях о Колочской, Тихвинской и Оковецкой иконах Пресвятой Богородицы полностью отсутствует, хотя оно вполне обычно для агиографической нарративной традиции. В этом отношении автор «Повести о Казанской иконе» превосходит своих предшественников-мариологов, сопрягая фактологию с рефлексией под стать многим восхвалителям подвигов святости во Христе. С ним разве что можно сравнить автора «Повести об иконе Богоматери Выдропусской» ${ }^{\text {о }}-$ звенигородского князя Георгия Токмакова, который тоже сопровождает свой рассказ об истории чудотворной святыни некоторыми рассуждениями.

Далее в сочинении Анонима-Гермогена следует рассказ об обретении и прославлении образа Богоматери в Казани. Он написан в простой, лишенной стилистических вычурностей, ясной манере, содержательно основан

го «Повесть душеполезна о чюдотворном образе Пресвятыя Богородицы, иже в Новгородской области в веси нарицаемей Выдропуске...» [23, с. 22-28]. Далее текст памятника цитируется по этому изданию. 
на использовании ряда сюжетно-повествовательных мотивов, хорошо известных по другим сказаниям об иконах, а в некоторых случаях и новых относительно литературной традиции.

Итак, в исследуемой повести обнаруживаются:

I)Мотив чудесного предуведомления с волеизъявлением. Дочери некоего воина, десятилетней девочке Матроне во сне икона Пресвятой Богородицы повелевает сообщить духовному и светскому начальству о месте ее сокровенного нахождения и необходимости ее обнаружения:

«Сице нача являтися девицы оной, ейже имя преди рекохом, икона пресветлая Божия Матери, и веляше ей почти во град и поведати про икону Богородицьну, еяже виде, архиепископу и воеводам, дабы шед выняли образ Пречистые Богородицы от земленых недр; и место поведа ей, идеже последи обретоша драгаго бисера честное сокровище, чюдную икону Богородицыну...».

В «Сказании» о Колочской иконе этот мотив отсутствует. Герой сказания Лука просто, без каких-либо предварительных знаковых событий в своей жизни и не будучи божественным собеседником, «на некоем древе в некоем месте обрете икону Пречистыя Богородицы». Нет означенного мотива и в «Сказании» об Оковецкой иконе, согласно которому некий чернец Стефан принародно находит чудотворный образ Богоматери на Пырыщенском городище, «на сосне, на сучку», в месте, между прочим, не состоявшейся воровской сходки ради обмена крадеными лошадьми и коровами. Зато в «Сказании» о Тихвинском образе мотив мистического указания на волю Божию проявляется в рамках более сложного сюжета: после явления «на воздусе» в нескольких местах Новгородской земли икона Богоматери чудесно останавливается на реке Тихвинке. Здесь возводят храм и на его освящение созывают через гонцов народ. Один из них, некто Юрыш, «муж благоверный и чистый житием», выполнив порученное и возвращаясь домой, в канун праздника Успения оказывается «в пустыне», ощущает дивное благоухание и святость этого места, видит явившихся ему Пресвятую Богоматерь и святителя Николая Угодника, благоговейно вступает с ними в диалог и получает божественное указание о водружении на новом храме деревянного креста. Как видно, сценичность и драматургичность «Сказания» о Тихвинской иконе в «Повести о Казанской иконе» сведены к схеме. 
2) Мотив скепсиса и равнодушия по отношению к свидетельствам визионера. Матрона рассказывает матери о своем сновидении. Та не верит. Сон повторяется. Мать упорствует в невнимании к рассказу дочери:

«Девица же убо, юна и несмыслена, бояшеся поведати, и абие едва поведа матери своей, мати же глаголы ея ни во что же вменив. И последи же убо в видении не единою являшеся ей пресветлая и чюдная она икона, и веляше ей без сумнения сие видение поведати. Девица же не единою, но и многажды сказоваше матери своей явление чюдные тоя божественыя иконы, веляше ей без сумнения поведати сие видение».

В «Сказании» о Колочской иконе ни о таинственном указании, ни о народном неверии не сообщается. Напротив, люди с молитвенной радостью и благоговением встречают Луку с обретенной им чудотворной иконой Пресвятой Богородицы. Не реализован мотив неверия и в «Сказании» об Оковецкой иконе. А вот «Сказание» о Тихвинской святыне обнаруживает иное повествовательное решение. В нем мотив неверия разработан в рамках сюжетного действия. Вернувшись в Тихвинский погост, Юрыш сообщает «священником и всему народу» о своей мистической встрече и о полученном им указании не ставить на строящемся храме железный крест. Но церковный мастер по общему решению поступает вопреки словам Юрыша. И происходит чудо. Ветер сбрасывает мастера, правда без вреда, с верха церкви на землю. Случившееся вразумляет людей, на нововозведенном храме во имя Успения Пресвятой Богородицы ставят крест деревянный, воля Божия исполняется, православные молитвенно торжествуют. Сказание, таким образом, наглядно демонстрирует силу божественного промысла и предопределения. Подобной изобразительности нет в «Повести о Казанской иконе», ее автор вместо драматизированного рассказа предложил своему читателю нонфигуративное описание. Но все же идейная напряженность данному произведению присуща, ибо мотив неверия звучит в нем весьма настоятельно. Оказывается, не только мать глуха к рассказу Матроны, кстати, все же поверившая своей дочери. Рассказ тайнозрительницы проигнорирован начальством Казани и светским, и духовным: «Они же убо (воеводы. - В.К.) неверием одержими о пречестней Пречистыя иконе, о ней же девица поведа, и ни во что же вмениша... Архиепископ же не внят речем ея и отосла ю безделну». Да и среди людей 
весть о месте потаенного сокрытия образа Пресвятой Богородицы не находит поддержки: «Пойде убо жена та (мать Матроны. - B.К.) к дому своему, поведая всем людем о чюдней иконе, како видение виде дщи ея. Людие же дивящеся о глаголех ея и отхождаху, не внимающе речем их». Это настоятельное указание в повести на неверие, несомненно, адресовано обществу, являющему слабость веры и равнодушие к тайнам Божиим.

3) Мотивы необычного света, устрашения, священной оторопи. Поначалу, как отмечено, мать не верит рассказам своей дочери. И тогда икона Богоматери является Матроне в огненном сиянии, уже грозно повелевая исполнить волю Божию:

«Во един же убо день случися девицы оной, ейже имя выше надписахом, спати в полудне - и внезапу девица обретеся посреди двора своего, в нем же живяше, и абие явися ей чюдная и пресветлая Богородицына икона страшным огненным образом, лучи испущая огнены пресветлы и страшны зело, яко мнетися ей от пресветлых тех луч, сияющих от иконы, сожжене быти. И глас бысть от образа страшен, к девище глаголющь: “Аще убо не повеси глагол моих и не поидеши от земленых недр выняти образа моего, аз же убо имам во иной улицы явитися, или во ином граде, ты же имаши болезнена быти, дондеже иживота зле гонзнеши!" Девицаже, от страшнаго сего видения зело ужасшеся, паде на землю и бысть яко мертва, и лежаше на земли на мног час».

«Сказание» о Колочской иконе абсолютно лишено мистического начала, и в его содержании нет ничего подобного. В «Сказании» об Оковецкой святыне чудо описывается буднично, без интереса к его тайне, использован только мотив света, но в неразвитом с точки зрения изобразительности и оценочных характеристик виде: «И старец Стефан крылошанин снял чудотворный Пречистыя образ, и ступи с нею с колоды на землю. И в те поры, яко буре или ветру сильну уторгшуся вскоре шунул (затих $\left.{ }^{\mathrm{II}}\right)$, и в той час бысть свет необычен, [якоже] всем людем, ту на городищи том зрящим, дивитися свету тому необычному». Несколько полнее означенные мотивы

II В. И. Далем зафиксировано похожее слово: «унать, щунять, щунить, счувать, счунить (заставить, почуять, почувствовать), журить, усовещевать, увещевать; унимать, бранить, претить что. || Вят. Я щунул его на дороге, встретил и остановил. Щунуться, опомниться, образумиться» [42, с. 678]. 
реализованы в «Сказании» о Выдропусской иконе, тоже, подобно колочской и оковецкой историям, жанрово близкой к бытовым повестям: один из героев произведения, некий воин, выкравший икону Богоматери из Георгиевской церкви в новгородском селе Выдропуске, поместил ее в храме святителя Николая Мирликийского в своей вотчине, в Муромской земле, но однажды икона во время пения канона на глазах у того воина и всего народа покидает место своего нового нахождения и возвращается в Выдропуск. Раскаявшись в содеянном, воин отправляется вслед за ней и в церкви великомученика Георгия вновь видит «образ пречистыя Богородицы Одигитрия стоящ на своем месте, яко солнце светящеся. Он же от страха паде и лежа на мног час яко мертв; наипаче ста битися главою своею о помост церковный и умилне плакати, милости прося, и каатися грехов своих». Интересный пример представлен «Сказанием» о Тихвинской иконе. В нем все указанные выше мотивы играют особенную роль, ибо вместе с другими деталями описания формируют кинематографически более наглядную и динамичную картину тайнозрительства: «Егда ж возвратися посланный муж той (Юрыш. - В.К.) из веси, гряды к церкви, проходя пустынное место... сльшавшу ж ему, яко ото множства фимияна и благодати святого Духа свящати место то и яко хотящу Богу показати милость свою на сем месте, иж чюдесем быти Бог и пречистые его Матери. И абие внезапу узрить чюдное видение: жену в богряне ризе одеянну и неизреченным светом сияюшу, на соснове колоде седящу в пустыни и пред нею стояща мужа светла, сединами украшена, во святительских ризах. Он же сия видев, от страха убоявся и паде яко мертв. Светлый же он муж предстояй прикоснувся его и рече ему: “Иди, человече, где ныне ставят церквь во имя святыя Богородицы... и хотят поставити крест железен на церкви. И ты глаголи священником и всему причту и повели поставити крест древян, зане ж Пречистая на своем храме железну кресту не изволи быти...”. Посланный ж муж от страха яко от сна возбудився и отвеща со дерзновнием, рече: “Господи, не имут ми веры”. Светлый же той муж рече: “Аще не имут ти веры, будет знамение”. И абие невидими быша седящая она жена и светлый той муж». Однако относительно нарративной реализации вышеозначенных мотивов все-таки нужно отдать предпочтение «Повести о Казанской иконе». Уступая, в частности, «Сказанию» о Тихвинской святыне в сценичности, рассказ Анонима-Гермогена в эпизоде таинственного прозрения, как показывает сравнение, более репрезентативен в плане воспроизведения особенностей 
необычного, чудесного явления и переживания, обстановка мистической встречи, горняя «внешность» умозримой святыни и состояние визионера выписаны в нем более яркими и насыщенными красками. Важно также отметить уникальную деформацию литературной традиции, зафиксированную авторами рассматриваемой повести: по их свидетельству, божественное волеизъявление было ниспослано тайнозрительнице Матроне именно от иконного образа, а не как обычно, - напрямую от самой Богоматери. Трудно сказать, отражает ли данная событийная деталь специфику авторского богословского сознания, но для восточно-христианской мариологии она нова.

4) Мотив использования в качестве фактологических деталей сакральных чисел, которые устойчиво встречаются и в библейских текстах и во всей литературной традиции Средневековья [I8, с. I8-I9], а также скрытого числового топоса ${ }^{\mathrm{I}}$. Рассказ Матроны начальствующим Казани пришелся на 7-й час дня, а обретение иконы произошло в І2-й час того же дня, 8 июля, т. е., получается, в I5-й день после пожара. Любопытно, что и повесть написана в I5 год после пожара, о чем уже прямо говорит ее составитель: «Пть убо к десятим летом преидоша явлению чюдотворныя Богородицыны иконы». Можно было бы эти детали, особенно промежуток времени между казанским пожаром и обретением образа, прямо не обозначенный, но составивший ровно I5 дней, отнести к разряду совпадений. Но число I5, как известно, во-первых, устойчиво связано с общехристианским преданием о Богоматери и с Ее почитанием [18, с. 52-71], во-вторых, довольно последовательно обнаруживается в мариологических контекстах древнерусской оригинальной агиографии [I8, с. I30-I40]. Именно это позволяет предположить не то чтобы предумышленность его явного и неявного присутствия в тексте «Повести о Казанской иконе», а возможное придание ему автором (по известной ассоциации) дополнительной знаменательности. То, что русские книжники к подобным деталям относились серьезно, доказывается, например, историей текста «Сказания» о Колочской иконе. Так, один вариант летописного рассказа об этой святыне - «в граде Можаице явися знамение в Колочи: Лука с иконою пречистою от града за 20 верст» - был вытеснен

\footnotetext{
I2 В данном случае под довольно неоднозначным для литературоведения понятием «топос» $[21 ; 33]$ подразумевается устойчиво повторяющаяся сюжетная компонента, общее для множества произведений место, переходящая из текста в текст повествовательная деталь, фактологический штамп, словесная формула.
} 
другим вариантом - «створися знамение в отчине князя Андрея Дмитриевича от Можайска I5 верст» [I5, с. I49]. Подобную корректировку обнаруживает и история «Повести о Темир-Аксаке». Согласно версии Б произведения монгольский хан пришел с огромным войском на Русь в I395 г., но, простояв «на едином месте две недели», не решился приступить к наступательным действиям: побужденный неожиданным страхом он «отыде в землю свою» в тот самый «день и час», когда «прииде на Москву икона Пречистыя», образ Владимирской Богоматери, завершив крестный ход из Владимира [І2, с. I34]. По утверждению же составителя редакции А, Темир-Аксак простоял на Дону не две недели, а все «I5 дний»; при этом и молитвенный вынос знаменитой иконы из Владимира состоялся именно I5 августа, в праздник Успения Пресвятой Богородицы [38, с. І24-І28]. Еще более усилена была таинственная знаменательность числа I5 в XVI в. Согласно новой обработке предания, ханхромец ретировался не только в I5-й день своего стояния и не только в день «сретения» Владимирской святыни в Москве; он бежал, устрашенный некоей «женой» - Богородицей, как поясняет автор данной редакции, - явившейся ему в этот день в сновидении «с множеством воинства» [27, с. I59-І6о].

Вероятно, день прославления чудотворной Казанской иконы Богоматери, 8 июля ${ }^{13}$, имел еще и реальное историко-политическое значение. Дело в том, что, согласно, например, Вологодско-Пермской, Иоасафовской и Никоновской летописям, этот день является кануном даты первого взятия Казани в 1487 г. войском великого Московского князя Ивана Васильевича III [29, с. 388], - события, память о котором, между прочим, с тех пор, судя по уставным предписаниям, отмечалось празднично: «В той же день (июля 9) великаго князя воеводы в лето 6995 были в Казани и град взяли, и царя с царицею поимали, и уставиша праздник празновати» ${ }^{14}$. Таким образом, факт явления Казанской иконы Богоматери сопрягался с фактом воспоминания о первом взятии Казани в прошлом и, возможно, с фактом просвещения Казанской земли после ее покорения в настоящем.

\footnotetext{
I3 Встречающееся в научной литературе представление о том, что явление Казанской иконы произошло 9 июля [30, с. 38, прим. 8] ошибочно [39, с. I79].

I4 «Поледование церковнаго пениа и собраниа вселетнаго устава святых отец правила, преимея тропоря и кондакы господскым праздником Христовым, и пречистей Его Матери, и нарочитым святым, и прочим, им же поется “Бог Господь” и им же “Аллилуиа” от месяца септябриа до месяца августа» [3I, л. І20I].
} 
5) Мотив личного примера в противодействие неверию. После безуспешных призывов к народу поискать святыню мать Матроны начинает сама копать землю на чудесно указанном месте. Ей после некоторых колебаний вторят люди. Но для той и других эти усилия оказываются неудачными:

«Она же, взем заступ и пришед к показанному месту, нача копати много время, и не обрете искомаго. Помале же убо начаша и инии копати, и все уже место воскопаше, ничто же обретше».

Эта подробность истории о Казанской святыне вполне оригинальна. Предания об иконах Тихвинской и Колочской, а также Владимирской, «Знамение», Оковецкой и Выдропусской ничего похожего не содержат. Нельзя не отметить особого звучания рассказа об инициативе матери в контексте настоятельной констатации всеобщего неверия свидетельству и указанию ее дочери как провозвестницы воли Божией. От данной подробности, несомненно, веет социально-психологической правдой отражения реального духовного состояния казанского общества, о чем в повести прямо сообщают авторские отступления.

6) Мотив обретения святыни на пепелище. Матрона присоединяется к ищущим и именно ей (замечу, непорочной отроковице) открывается тайна и она обнаруживает икону:

«Предиреченная же она девииа нача копати на месте, идеже пещь бе, таже и прочии с нею. И яко выкопаша мало боле двою лактий - оле чюдо! явися чюдотворная икона Владычицы нашия Богородицы и Приснодевы Мария, честнаго ея Одигитрия, купно с Превечным Младенцем, Господем и Богом нашим Исусом Христом!»

В сказаниях об иконах Пресвятой Богородицы обычно рассказывается о возведении храмов на месте их чудесного явления или обретения. Как правило, эти храмы затем сгорают, но находившиеся в них святыни оказываются вновь обретенными в пепле без вреда от огня. Ярким примером, подтверждающим данную традицию, является «Сказание о Тихвинской иконе». После первого храмового пожара «на том месте поставиша вторую церковь древяну, тако же и чясовню. И стояла вторая црковь 5 лет и грех ради наших, небре- 
жением паки вторая церковь згорела от свещи, и не остави ничесо ж в ней. А чюдотворную икону обретоша в пепелу Божиею милостию и благодатию всю целу и огнем не вредиму ни единым власем». Похожее свидетельство содержится и в «Сказании» о Выдропусской иконе: «Бысть в лета отец наших за грехи наша пожар велик на месте сем, храм же великаго мученика Христова Георгия до основания згоре со всем зданием церковным, после же того великаго пожара начаша росчишати церковное место и обретоша образ сей в пепеле к земли ниц лежащ, благодатию Божиею сохранен, ничим же врежен бысть от огня, но токмо мало с тылу дска посмеде». Однако в рассказе Анонима-Гермогена мотив чудесного обнаружения не поврежденной огнем святыни, как можно видеть, разработан с более выразительной конкретикой: есть определенный персонаж, девочка-визионер, есть известное место действия, причем не храмовое пожарище, а погорелые руины обычного дома, и есть точно указанный объем произведенного действия. Традиционная абстрактная схема обретает, соответственно, зримое содержание, отражающее и уникальную и парадоксальную ситуацию: икону ищут и находят под бывшим очагом, - там, где ее никак не должно было бы быть. Любопытно, что позднейший источник, Пискаревский летописец ${ }^{15}$, сообщает о предыстории прославившейся в Казани святыни: «Того же (7087/І579. - В.К.) году явися Пречистая Казанская некоей девице третицею, а скрыто бысть многое время. Как царь Иван пленил Новгород Великий 78-го, и в то время некий мурза казанской взя некую пленницу девицу, и тот образ та девица привезла, тайно молилася и преставися, а тот образ скрыла в землю» [28, с. г93]. Эта информация вносит путаницу, ибо икону, согласно повести, все-таки нашли не просто в земле, а там именно, где прежде была печь.

7) Мотив качественной оценки обретенного образа. Явившая себя икона не только сияет, что подчеркнуто дважды, но и выглядит как совершенно новая и написанная по совершенно необычному иконографическому типу, о чем сообщается, правда без конкретизации, тоже дважды:

а) «Самый же чюдотворный образ светлостию чюдне сияя, якоже внове вапы начертан. Земному же праху никако же коснувиуся чюдному тому образу, якоже сами видехом...»,

I5 По мнению одних исследователей, он был составлен в середине XVII в. [37], другие же датируют его началом второго десятилетия XVII в. [43]. 
b) «И виде Пречистые образ, якоже нов дар пречюдне светяшеся, и дивися убо зело: такова переводом образа не видеша нигдеже...»,

c) «...такова образа переводом нигде же не видеша».

Сам по себе мотив необычного сияния в рассказе о факте чудесного обретения святыни вполне типичен. Он использован, например, в «Сказании» о Тихвинской иконе: «И явися на Тихвине сицевым образом: стоя на горе, на воздусе, и возсия икона Пречистые светом неизреченным». При этом в предании о Колочской, Оковецкой и Выдропусской святынях этого мотива нет. А вот имеющаяся в рассматриваемой повести характеристика отличительных изобразительных особенностей изъятой из земли иконы (к сожалению, только общая) - факт литературно новый. Нечто подобное обнаруживается и в «Сказании» об Оковецком образе: «А та чудотворная икона невелика, воротная, письмо старинное». По-видимому, есть основания думать о стремлении Анонима-Гермогена не только рассказать о необычных обстоятельствах явления в Казани чудотворного образа Богоматери, но и отметить, хоть и весьма скупо, его художественную уникальность и неповторимость. Кроме того, по интересному соображению новейшей исследовательницы, текст повести позволяет полагать, что ее авторы отчетливо понимали смысловую суть чудесно обнаруженной святыни: «явися чюдотворная икона Владычицы нашия Богородицы и Приснодевы Мария, честнаго ея Одигитрия, купно с Превечным Младенцем, Господем и Богом нашим Исусом Христом». Иными словами, извлеченный из-под земли, но сияющий новыми красками, образ Богоматери, считавшейся покровительницей России (ведь в повести прямо говорится об иконе Марии «Одигитрии», т. е. путеводительницы. - В.К.), должен был символизировать собой возобновление и торжество Православия в Казани после ее окончательного присоединения к Московскому государству [29, с. I97-198], особенно, стоит добавить, в условиях отмеченного повестью же конфликтного напряжения умонастроений среди местного населения. Кстати, святитель Гермоген, помимо исследуемого произведения, составил еще и службу Казанской иконе Богоматери [40, с. I30-I3I], издание которой, - вероятно, около I590 г. - знаменовало собой утверждение «культа» иконы «в качестве общегосударственной святыни» и важность для Московского царства укрепления границ на Востоке [зо, c. $26 ; 29$, с. $389-390]$. 
8) Мотив ликования и благоговейного воодушевления людей при обретении святыни. Собравшийся к чудесной находке народ молитвенно восславляет Пресвятую Богородицу:

«Девииа же взем Пречистые образ со страхом и трепетом и радостию и поставиша на том же месте. Людие же ту сущии возопиша, проповедающе немолчными гласы явления божественыя тоя иконы. И вскоре стекошася безчисленое множество благочестивых народа, вопиюще со слезами: "Владычиие, спаси ны!!”.

«Сказания» о Колочской и Оковецкой иконах ничего не сообщают о подобной реакции церковного народа. Тогда как в «Сказании» о Тихвинском образе означенный мотив хорошо развит: «И собрашася люди мнози на место то, и видеша людие велие чюдо: икону пречистые владычицы нашея Богородицы и приснодевы Мария на воздусе стоящу, ничим не держиму, и дивяся, со слезами молящеся пренепорочной владычице нашей Богородицы и из нея ж неизреченно рождьшемуся превечному Младенцу Христу Богу нашему. Христолюбивии же ти людие с велицым благодарением хвалу воздав Богу и пречистей его Матери...». Похожая картина рисуется в «Сказании» о Выдропусской иконе. Когда икона была найдена на пепелище после церковного пожара невредимой, «Селяне же, слышавше, и скоро текоша во храм видети чюдо Божии Матере - с женами, и з детьми, и со младенцы, с великим тщанием и обретоша по словеси понамареви. И бысть радость велика в веси той о чюдеси заступницы Богородицы, еще же от радости и слезам пролитию бывшу многу». Сравнение вместе с тем обнаруживает, что «Повесть о Казанской иконе», следуя традиции, привносит в развитие выше указанного мотива важную коррективу: сначала юная дева, ребенок, трепетно поклоняется обретенной святыне и лишь затем ее неколебимая вера передается всему церковному народу. Так завершается прежде обозначенная в рассказе Анонима-Гермогена тема неверия призывам провозвестницы относительно божественного волеизъявления и ее упорной борьбы за народное и церковное следование этому волеизъявлению.

9) Мотивы крестохождения к святыне, раскаяния начальствующих и общей радости. Архиепископ, «первые града» и «освященный собор» колокольным звоном и крестным ходом воздают честь чудесно, по определению Божию, найденной и явившей себя иконе: 
«И послаша весть к архиепископу и к первым града, яко обретоша Богородицын святый образ. Архиепископ же повеле скоро в колокол звонити и пойде со кресты на место то со всем освященным собором, идеже обретоша чюдную Пречистые икону, с воевоеды и со множеством народа. И виде (архиепископ. - В.К.) Пречистые образ, якоже нов дар пречюдне светяшеся и дивися убо зело: такова переводом образа не видеша нигде же, и недоумевашеся, страхом убо и радостию одержим, неверия ради своего, с плачем моляся и милости прося и прощения о согрешении. Сице же и воеводы с плачем просяще милости, еже согрешиша к чюдотворному Пречистые образу нерадением и неверием. И весь народ града стекашеся на дивное то божественое чюдо, веселящеся со слезами, и радостною душею хвалу Богу и Богородицы о обретении многобогатаго и безценнаго сокровища возсылаху».

В данном аспекте «Повесть о Казанской иконе» уникальна. Разве что только мотив радости по случаю чудесного события известен сопоставляемым с ней сказаниям. Но более важно, что в повести указанные мотивы несут очевидную идейную нагрузку, ибо способствуют созданию идеальной картины церковного единодушия и единения относительно восприятия свершившегося чуда, раскаяния в духовной черствости перед святыней и молитвы пред ней с благодарностью и надеждой на божественное милосердие и помощь. А картина такого единодушия и единения была жизненно необходима в совсем недавно присоединенной к Московскому государству Казани, где, как утверждается в предисловии к повести, православие было в поругании и уничижении у неверных и иноязычных народов (см. выше).

Iо) Мотив чудесных исцелений. Два чуда прозрения во время чествования иконы - неполного (прозревший слепец Иосиф не воздал за это благодарения Богоматери и «малу стезю зряще») и полного (прозревший слепец Никита воздал должное благодарение и «получи здравие»). Сообщения либо в общих выражениях, либо в сюжетно организованной форме о подобных чудесах содержатся во всех сказаниях об иконах Пресвятой Богородицы, как и вообще в агиографических текстах.

II) Мотив описания событий, последовавших за чудом явления или обретения иконы. В «Повести о Казанской иконе» сообщается о повелении Ивана Грозного, получившего письменное донесение о всех событиях в Ка- 
зани, а также копию чудотворного образа Богоматери ${ }^{\text {16}}$, возвести на месте прославления последнего Одигитриевский храм и устроить при нем девичий монастырь, где приняли пострижение Матрена и затем ее мать:

«Благоверный же изарь государь и великий князь и сынове его повелеша на том месте иерковь поставити, идеже обретеся чюдотворная икона. И монастырь дев повеле устрочти, и келии поставити, и ограду монастырю оградити, и милостыню доволну повеле дати из своей царские казны священному собору и игуменье, и 4 сестрам урок летний, - еже и бысть. И церковь поставиша во имя святыя Богородицы честнаго ея Одегитрия древяну, и ограду монастырю сотвориша.

Честную же ону и чюдотворную икону Пресвятыя Богородииа отнесоша в монастырь с молебным пением, со кресты, архиепискуп и боляре со всем народом проводиша честно. Предиреченную же девииу Матрену постригоша в том же монастыри, и наречено бысть имя ей Мавра во иноких. Не по мнозе же времени пострижеся и мати тоя девищы».

Биографии лиц, связанных с главным чудом явления или обретения иконы, как и рассказ о последующих событиях, в «Сказаниях» о Колочской и Выдропусской иконах весьма развернуты. То же можно утверждать и относительно «Сказания о Тихвинской иконе», в котором, правда, ничего не сообщается о последующей судьбе пономаря Юрыша, получившего при таинственной встрече с Пресвятой Богородицей повеление о кресте на Успенской церкви, построенной на месте последнего чудесного явления образа Одигитрии. В «Сказании» об Оковецкой иконе несколько персонажей фигурируют фрагментарно, но при этом весьма подробно описаны события, сопряженные с церковным признанием чудотворной святыни.

Указанными сюжетными мотивами, традиционными и новыми, исчерпывается главная часть рассматриваемого произведения, - рассказ о чудесном обретении в Казани во время царствования Ивана Грозного иконы Пресвятой Богородицы и о ее прославлении. Как показывает сравнение с другими жанрово близкими литературными памятниками, в данной части текст сочинения Анонима-Гермогена построен на основе описания напря-

I6 Дошедшие до нашего времени первые списки явленной иконы датируются концом XVI в. [26; 46]. 
женной коллизии общественных настроений и поступков: свидетельство девочки-визионера о божественном волеизъявлении наталкивается на недоверчивое сопротивление общества в лице сначала ее матери, а затем светского и духовного начальства, да и казанского населения; обретение же иконы в таинственно открытом месте приводит к торжеству веры и народного единения. Однако рассказ об этой истории в целом, как можно полагать, литературно усреднен относительно драматургического развития сюжета (повествование описательно, в нем, прежде всего, отсутствуют монологи и диалоги персонажей). Дискурс рассказчика заметно сдержан также и относительно стилистики и эмоциональной напряженности изложения и вместе с тем свободен от простодушной гипертрофированности восприятия и интерпретации чуда, характерной для народного почитания святынь и народной поэтизации преданий о них. Наконец, в произведении с фактологически ограниченной умеренностью характеризуются исторические подробности и детали. Например, не названы имена казанских воевод, при которых произошло чудо прославления богородичного образа, схематично проработаны поведенческие эпизоды. Исключение, пожалуй, составляет свидетельство о причастности к его прославлению автора повести:

«Мне же тогда в чину поповсте святаго Николь, иже зовется Гостин; каменосердечен же сый, но обаче прослезихся, и припадох к Богородицыну образу, и к чюдотворней иконе, и к Превечному Младениу Спасу Христу, и потом поклонихся архиепископу, и благословение испросих, о еже бы повелел взяти ми пречюдную Богородицыну икону. Архиепископ же благослови мя и повеле взяти ми. Аз же, аще и недостоин сый, но обаче со страхом и радостию прикоснухся чюдотворному тому образу, и взях з древия, иже бе поткнено на том месте, идеже и в земли бе святая та и чюдная икона. И по повелению архиепископа, с прочими святыми иконами и честными кресты, идох со иконою в близ сущую ту церковь святаго Николь, иже зовется Тулский. И тамо молебному пению совершившуся, и паки архиепископ со всем освященным собором, и первии града, и все множество православных народа со женами вкупе и детми, вслед святых икон во град идущи. Кновоявленней же чюдотворней иконе безчисленое множество народа реяхуся, и друг друга поревающе; инии же по главам инех ходяще, $\kappa$ чюдотворному образу темены прикасахуся. Мне же, по повелению архиепископа, народа ради с чюдотворною иконою медлено идущю, но обаче толикое 
множество народа не соврати мя ни на десно, ни на шуе: несох бо Носящаго всю тварь, и того Рождешей пречюдную и чудотворную икону».

Бесспорно, фрагмент этот, весьма ярко воспроизводящий обстановку всеобщего эмоционального, духовного, молитвенного воодушевления в связи с чудом, написан был самим святителем Гермогеном. Примечательно отразившееся в нем живое чувство волнения от нахлынувшего воспоминания.

Помимо основной части «Повести о Казанской иконе», несомненным интересом обладают вводный и заключительный разделы произведения. По всей видимости, они принадлежат преимущественно перу святителя Гермогена. Правда, нужно отметить, что во введении к повести (на это указывал, но без конкретики, еще А. Эббингхаус [49, s. 2Іо]) обнаруживается довольно большой фрагмент, построенный на заимствовании из «Слова похвального Покрову Пресвятой Богородицы» Пахомия Логофета:

«Понеже убо человеческий род обыче и святых памяти духовные с похвалами празновати, а иже Пресвятей и Преславней Царице - иарски празники празновати, Пречистыя Богородииы и Приснодевы Мария! Сию попремногу паче онех любовию почитати должни есмы, та бо есть божественый покров рабом своим, и притецати к тихому сему и доброму пристанищу, скорой помощнице, готовому и теплому спасению - покрову Девыя; и яко вышшей и паче всех тварей вышшую похвалу принести, яко Цариче и Владычице, Царя и Владыку всех рождьшую!

Тоя бо ради праматерняя клятва потребися и Адам от вечных уз свободися, и Бог к нам примирися! Тогда бо Ияковля лествииа утвердися, Богу хотящу по ней снити и человеком путь сотворити к небесным, и человецы со аггель во едино быша. Не ктому, якоже тогда, со Ияковом древле борется, ибо Твореи, Ияковль на землю сниде, погибшую драхму взыскати хотя и Отиу принести. Темже пророцы тогда возрадошася, своему пророчеству збытие зряще! Тогда убо Давид, видев от семени его правнуку родившуся, бряиая в гусли, играя духом. глаголя: «Слыши, дщи, и виждь, и приклони ухо твое!» Темже тогда не токмо пророи,ы, но и превышняя и земная тварь съпразноваше.

Ныне же паки приспе новый празник честный Владычицы нашея Богородиць - честнаго ея образа иконы Одигитрия, крепкия помощница, да познают вси, яко не токмо, егда в мире бяше, ходатайственое к своему Твориу и Сыну 
показоваше, но и паче и по преславном своем преставлении от земных в небесная непрестанно милостивно нас присешая!» ${ }^{17}$

Кому именно - Анониму или же Гермогену - принадлежит это заимствование, пока не установлено: необходимо текстологическое исследование всех списков памятника. Но априори понятно: и оно само по себе, и вообще вся рефлексия от лица автора в составе произведения вполне типичны для христианской средневековой литературной традиции и по тематике, и идейно, и стилистически. В первую очередь, это касается личностных самооценок, а именно признания собственного литературного недостоинства и покаяния в долгой неозабоченности относительно подробного описания всего случившегося в Казани.

В завершение обзора памятника следует отметить, что внимания достойны своим живым изложением, а также бытовыми и историческими деталями, включенные в состав повести рассказы о чудесах исцелений по молитвам, обращенным к Пресвятой Богородице через Ее чудотворный образ, - чудесах, происшедших уже в монастыре, основанном на месте его обретения, свидетелем которых также был святой Гермоген. Впрочем, эти рассказы, как и введение с заключением, требуют отдельного историкофилологического анализа.

Итак, «Повесть о Казанском чудотворном образе Богоматери» является вполне типичным памятником древнерусской литературы. Звучание новых мотивов в представленной ею истории, в сущности, ничего не меняет. Сюжет, композиция, язык строго ориентированы на каноны церковной литературы. Автор произведения (Аноним-Гермоген), бесспорно, умелый писатель. Но писатель последовательно сдержанный, ориентирующийся на консервативно настроенного книгочея и потому твердо державший себя в жестких рамках официальной идейно-эстетической традиции и литературной нормы; писатель, соответственно, не осмеливавшийся (подобно, например, преподобному Иосифу Волоцкому, Ермолаю Еразму, Ивану Грозному или Андрею Курбскому) нарушать некий эмоционально нейтральный повествовательный дискурс эскападами развернутых и обогащенных разными цитатами богословских или публицистических суждений и оценок, поэзи-

I7 Подчеркнутое ср.: «Слово похвальное честному Покрову пресвятой Владычицы нашей Богородицы и Приснодевы Марии. Творение смиренного иеромонаха Пахомия» [7, с. 54]. 
ей образного мышления и яркой в плане выразительности, содержательно емкой, экспрессивно энергичной фразы. Впрочем, как можно судить по известному материалу, для жанровой группы сказаний об иконах означенные литературные черты вообще мало характерны. Между прочим, сюжетностилистическая нормативность сочинения Анонима-Гермогена контрастно оттеняется преданиями о Колочской, Оковецкой и отчасти Выдропусской иконах Пресвятой Богородицы, облеченными в форму драматургически организованного и стилистически близкого к живой русской речи нарратива. Это дает основания для определенных выводов относительно особенностей исторического развития русской литературы в Московской Руси второй половины XVI в. Действительно, художественная природа «Повести о Казанской иконе» в целом свидетельствует об известном процессе консервации и формализации литературной работы. Под давлением этого процесса, думается, словесно преобразовывалось и предание о Тихвинском образе, более схожее с преданием о святыне из Казани. А вот Колочская, Оковецкая и Выдропусская истории, бесспорно, указывают на зарождение в недрах средневекового литературного сознания эмбрионов поэтики и стилистики нового типа, связанных с преодолением и расширением канонической идейно-эстетической нормы. 


\section{Список литературы}

А.С. Материалы для истории Русской Церкви. Гермогена, патриарха московского, Сказание о явлении и чудесах от иконы пресвятыя Богородицы Казанской, писано в I594 г. (№ 982, 4, скороп., 36 лл.) // Чтения в Московском обществе любителей духовного просвещения. М., І880. Кн. 6, отд. 3. С. І-44. Агафонов И.С. Идеологические тенденции в нарративах Знаменского цикла XV-XVII в. // Древняя Русь. Вопросы медиевистики. 2015. № 4 (62). С. I6-22. Агафонов И.С. Икона «Знамение» - палладиум Новгорода: к истории формирования легенды // Молодые - науке: сб. науч. работ. М., 2013. С. 25-30.

Агафонов И.С. Памятники знаменского цикла: летописные и нелетописные нарративы XV века // Язык и текст. М., 20I4. № 3. С. I9-29.

$$
\text { Библиологический словарь и черновые к нему материалы П. М. Строева: При- }
$$
ведены в порядок и изданы под редакцией академика А. Ф. Бычкова. СПб., г882. (СОРЯС. Т. 29). [2], 532, 8 c.

6 Библиотека литературы Древней Руси. СПб.: Наука, 200о. T. 9: Конец XIV-первая половина XVI века. 566 с.

7 Библиотека литературы Древней Руси. СПб.: Наука, 2003. T. ı2: XVI век. 624 с.

8 Библиотека литературы Древней Руси. СПб.: Наука, 2006. T. г4: Конец XV-начало XVII века. 758 c.

9 Буланин Д.М. Сказание о иконе Богоматери Иверской // Словарь книжников и книжности Древней Руси. Л., І989. Вып. 2. Ч. 2. С. 362-365.

Буланин Д.М. Токмаков Георгий Иванович // Словарь книжников и книжности Древней Руси. Л., І989. Вып. 2. Ч. 2. С. 43І-432.

II Гребенюк В.П. Икона Владимирской Богоматери и духовное наследие Москвы. М.: Биоинформсервис, 1997. 210 с.

I2 Ермолинская летопись // Полное собрание русских летописей. СПб., I9Iо. Т.23. V,24I c.

I3 Жуков А.Е. К вопросу об автографах патриарха Гермогена // Вестник «Альянс-Архео». М., 2ог6. Вып. г3. С. 3-22.

I4 Журова Л.И. «Сказание о Колочской иконе». Новосибирск: Изд-во СО РАН, 2000. 257, [2] c.

I5 Журова Л.И. Из литературной истории повести о Луке Колочском // Источниковедение литературы древней Руси / отв. ред. Д. С. Лихачев. Л., І980. С. I43-I54. Журова Л.И. Сказания о чудотворных иконах в структуре Лицевого летописного свода // Quaestio Rossica. Уральский федеральный университет, 20I5. № 3. C. I79-I99. 
I7 Кириллин B.M. Жанрово-тематические особенности сказаний об иконах // Очерки о литературе Древней Руси. Материалы для истории русской патрологии и агиографии. Сергиев Посад: Изд-во МДА, 2012. С. 207-2І4.

I8 Кириллин B.M. Символика чисел в литературе Древней Руси (XI-XVI века). СПб.: Алетейя, 2000. 320 с.

I9 Кириллин В.M. Сказание о Тихвинской иконе Богоматери «Одигитрия». Литературная история памятника до XVII века. Его содержательная специфика в связи с культурой эпохи. Тексты / ИМЛИ РАН, ОИДР. М.: Языки славянской культуры, 2007. 307 с., [9] л., ил.

Конявская Е.Л. Древнерусские сказания о чудотворных иконах: особенности нарратива // Нарративные традиции славянских литератур: от Средневековья к Новому времени. К юбилею члена-корреспондента РАН Е.К. Ромодановской. Новосибирск: Омега Принт, 20I4. С. 54-58.

Конявская Е.Л. Проблема общих мест в древнеславянских литературах (на материале агиографии) // Ruthenica. НАН України. Ін-т історії України; Наук. ред.: В.М. Ричка, О. П. Толочко. Київ, 2004. Т. 3. С. 80-92. Криза А. Летающие иконы Богородицы - покровители русского государства // Роль государства в историческом развитии России / Editor Szvák Gyula. Budapest: Russica Pannonicana, 20II. S. IOO-I2O.

23 Лавровский Н.Л. Повесть о чудотворном образе Богородицы, находившемся в Выдропуске // Летописи русской литературы и древности. М., І862. Ч. 3. С. І9-28.

24 Леонид, архим. Сказания и повести о святых чудотворных иконах // Русский архив. M., І88I. Кн. II (I). С. 5-6.

25 Малов Е. Казанский Богородицкий девичий монастырь: История и современное его состояние. Казань, I879. I42, XXI с.

26 Немтинова В.В. Образ Казанской Богоматери последней четверти XVI века из собрания Государственного музея изобразительных искусств Республики Татарстан: К истории открытия и реставрации одного из первых списков явленной чудотворной иконы // Чудотворный Казанский образ Богородицы в судьбах России и мировой цивилизации. Сборник материалов Международной научно-практической конференции: Казань, І9-2І июля 20І6 г. Казань: Центр инновационных технологий, 20І6. С. І29-ІІІІ.

27 Патриаршая, или Никоновская летопись // Полное собрание русских летописей. M., I965. T. II. VII, 254 C. 
28 Пискаревский летописец // Полное собрание русских летописей. М., І978. Т. 34: Постниковский, Пискаревский, Московский и Бельский летописцы. С. 3I-220.

29 Плюханова М.Б. «Кипъние свظта»: Русские Одигитрии в литургической поэзии и в истории. СПб.: Изд-во «Пушкинский дом», 20I6. 604 с., ил.; 24 с. цв. вклейка.

30 Поздеева И.В., Турилов А. А. «Тетрати... печатаны в Казанъ» // Древняя Русь: Вопросы медиевистики. М., 200I. № 2 (4). С. 37-49.

3I Псалтырь с восследованием // НИОР РГБ. Собр. рукописей Троице-Сергиевой лавры (ф. 304.I). № 32I (848). 2-я половина XVI в. І3І4 л.

32 Романова А.А. Сказание о иконе Богоматери Оковецкой (Ржевской) // Словарь книжников и книжности Древней Руси. СПб., 2004. Вып. 3 (XVII в.). Ч. 4: Т-Я. Дополнения. С. 864-866.

33 Руди T.P. Топика русских житий (вопросы типологии) // Русская агиография: Исследования. Публикации. Полемика / под ред. С.А. Семячко и Т. Р. Руди. СПб., 2005. C. 59-IOI.

34 Сказание о чудотворной Казанской иконе Пресвятой Богородицы: Рукопись святейшего патриарха Гермогена. С предисловием академика А.И. Соболевского. M., I9I2. 8 c.

35 Сказание об иконе Богоматери Римской. Перевод А. Ю. Никифоровой, предисловие А.М. Лидова // Реликвии в Византии и Древней Руси / ред-сост. А.М. Лидов. М.: Прогресс-Традиция, 2006. С. 225-237.

36 Соборник из 7І слова. М.: Печатный двор, г647. 2. 879 л.

37 Солодкин Я.Г. Пискаревский летописец // Словарь книжников и книжности Древней Руси. СПб., І993. Вып. 3 (XVII в.). Ч. 2: И - О. С. 269-274.

38 Софийская вторая летопись // Полное собрание русских летописей. СПб., I853. Т. 6: Софийские летописи. С. ІІ9-276.

39 Спасский С., архим. Полный месяцеслов Востока. М., І876. Т. 2: Святой Восток. XXII, 272, XII c.

40 Спасский Ф.Г. Русское литургическое творчество. М.: Издат. Совет РПЦ, 2008. 544 с.

4I Творения святейшего Гермогена Патриарха Московского и всея Руси. С приложением чина поставления патриарха. М., I9I2. [IV], ІІо с.

42 Толковый словарь живого великорусского языка Владимира Даля. 2-е изд. СПб.; М.: Изд-е М.О. Вольфа, І882. Т. 4: Р -Ү. 704 с.

43 Хазанова С.И. Пискаревский летописец: Происхождение, источники, авторство. М.: Изд-во Квадрига, 20I4. 220 с., І5 ил. 
44 Целкова Л.Н. Мотив // Введение в литературоведение: учеб. пособие / под ред. Л.В. Чернец. М.: Высшая школа, 2004. С. 230-236.

45 Чугреева Н.Н. Казанская икона Божией Матери // Православная энциклопедия. M., 20I2. T. XXIX: К - Каменац. С. I96-215.

46 Чугреева Н.Н. О явленном в I579 году в Казане образе Богородицы, ранних списках с него и позднейших воспроизведениях // Чудотворный Казанский образ Богородицы в судьбах России и мировой цивилизации. Сборник материалов. С. I84-г86.

47 Чудотворная Казанская икона Божией Матери. Заступница усердная рода христианского / А.М. Елдашев и др.; под ред. Ю. В. Андреевой. Казань: Центр инновационных технологий, 20I2. 356, [3] с.

48 Шмидт С.О. Сказания об афонских монастырях в новгородской рукописи XVI века // Древнерусская литература и ее связи с новым временем. М., I967. C. 358-360.

49 Ebbinghaus A. Die altrussischen Marienikonen-Legenden. Berlin, I990. 290 s.

50 Kriza A.A középkori orosz képvédő irodalom. I rész. Bizánci forrasok / Криза А. Древнерусские тексты в защиту икон. Russica Pannonicana, Budapest, 2оII. Ч. г: Византийское наследие. 324 с.

5I Petri Lambecii... Commentariorum de aug Bibliotheca caesarea Vindobonensi. Liber 8... quo continetur catalogus manuscriptorum codicum graecorum historicorum ecclesiasticorum... Vindobonae [Wien]; Typis Matthei Cosmerovij, ı679. [4] с., 788 стб.

\section{References}

I A.S. Materialy dlja istorii Russkoj Cerkvi. Germogena, patriarha moskovskogo, Skazanie o javlenii i chudesah ot ikony presvjatyja Bogorodicy Kazanskoj, pisano v I594 g. (№ 982, 4, skorop., 36 11.) [Materials for the history of the Russian Church. A tale of apparition and miracles of the icon of Our Lady of Kazan by Hermogenes, a Moscow Patriarch]. Chtenija v Moskovskom obshhestve ljubitelej duhovnogo prosveshhenija [Readings in the Moscow Society of the Lovers of Spiritual Engligtening]. Moscow, I88o, vol. 6, part 3, pp. I-44. (In Russ.)

2 Agafonov I.S. Ideologicheskie tendencii v narrativah Znamenskogo cikla XV-XVII v. [Ideological tendencies in the narratives of Znamensky circle of the $15^{\text {th }}-18^{\text {th }}$ centuries]. Drevnjaja Rus'. Voprosy medievistiki, 2015, no 4 (62), pp. I6-22. (In Russ.) 
3 Agafonov I.S. Ikona "Znamenie" - palladium Novgoroda: $\mathrm{k}$ istorii formirovanija legendy [Icon "Znamenie" as Novgorod's palladium: on the history of the legend]. Molodye nauke. Sb. nauchnyh rabot [The Young - to the science. Col. of essays]. Moscow, 20I3, pp. 25-30. (In Russ.)

4 Agafonov I.S. Pamjatniki znamenskogo cikla: letopisnye i neletopisnye narrativy $\mathrm{XV}$ veka [The works of zanmensky circle: chronicle and non-chronicle narratives of the $\mathrm{I}^{\text {th }}$ century]. Jazyk i tekst [Language and text]. Moscow, 20I4, no 3, pp. I9-29. (In Russ.) Bibliologicheskij slovar' i chernovye k nemu materialy P.M. Stroeva [Bibliological dictionary and drafts of P. M. Stroev]: Privedeny v porjadok i izdany pod redakciej akademika A.F. Bychkova [Revised and published by academician A.F. Bychkov]. St. Petersburg, I882. (SORJaS. T. 29). [2], 532, 8 p. (In Russ.)

6 Biblioteka literatury Drevnej Rusi [Library of the Old Russian literature]. St. Petersburg, Nauka Publ., 2000. Vol. 9: Konec XIV - pervaja polovina XVI veka [The end of the $\mathrm{I} 4^{\text {th }}$ - the first half of the $\mathrm{I} 6^{\text {th }}$ centuries]. 566 p. (In Russ.)

7 Biblioteka literatury Drevnej Rusi [Library of the Old Russian literature]. St. Petersburg, Nauka Publ., 2003. Vol. I2: XVI vek [I6 ${ }^{\text {th }}$ century]. 624 p. (In Russ.)

8 Biblioteka literatury Drevnej Rusi [Library of the Old Russian literature]. St. Petersburg, Nauka Publ., 2006. Vol. I4: Konec XVI - nachalo XVII veka [The end of the $\mathrm{I} 6^{\text {th }}$ - the beginning of the $I 7^{\text {th }}$ centuries]. 756 p. (In Russ.)

9 Bulanin D.M. Skazanie o ikone Bogomateri Iverskoj [A tale of the icon of Our Lady of Iver]. Slovar' knizhnikov i knizhnosti Drevnei Rusi [A Dictionary of Book Culture of the Old Rus']. Leningrad, I989, issue 2, part 2, pp. 362-365. (In Russ.) Bulanin D.M. Tokmakov Georgij Ivanovich [Tokmakov Georgij Ivanovich]. Clovar' knizhnikov i knizhnosti Drevnei Rusi [A Dictionary of Book Culture of the Old Rus'] Leningrad, I989, issue 2, part 2, pp. 43I-432. (In Russ.) Grebenjuk V.P. Ikona Vladimirskoj Bogomateri i duhovnoe nasledie Moskvy [The icon of Our Lady of Vladimir and spiritual legacy of Moscow]. Moscow, Bioinformservis, I997. 2IO p., 20 p., il. (In Russ.)

I2 Ermolinskaja letopis' [Ermolinskaya chronicle]. Polnoe sobranie russkih letopisej [Complete collection of Russian chronicles]. St. Petersburg, I9IO. Vol. 23.V, 24I p. (In Russ.)

I3 Zhukov A.E. K voprosu ob avtografah patriarha Germogena [On the question of Patriarch Hermogen autographs]. Vestnik “Al'jans-Arheo”. Moscow, 2016, issue I3, pp. 3-22. (In Russ.) 
I4 Zhurova L.I. "Skazanie o Kolochskoj ikone” [A tale of Kolchovskaya icon]. Novosibirsk, SO RAN Publ., 2000. 257, [2] p. (In Russ.)

I5 Zhurova L.I. Iz literaturnoj istorii povesti o Luke Kolochskom [From literary history of the tale of Luca Kolochsky]. Istochnikovedenie literatury drevnej Rusi [Source studies], ed. D.S. Likhachev. Leningrad, I980, pp. I43-I54. (In Russ.)

I6 Zhurova L. I. Skazanija o chudotvornyh ikonah v strukture Licevogo letopisnogo svoda [Tales of miraculous icons and the structure of the Litzevoy icon catalogue]. Quaestio Rossica. Ural'skijfederal'nyj universitet [Ural' Federal University], 20I5, no 3, pp. I79-I99. (In Russ.)

I7 Kirillin V.M. Zhanrovo-tematicheskie osobennosti skazanij ob ikonah [Generic and thematic specificity of tales about icons]. Ocherki o literature Drevnej Rusi. Materialy dlja istorii russkoj patrologii i agiografii [Essays on the literature of the Old Rus'. Materials on the history of Russian patrologia and agiography]. Sergiyev Posad, MDA Publ., 20I2, pp. 207-2I4. (In Russ.)

I8 Kirillin V.M. Simvolika chisel v literature Drevnej Rusi (XI-XVI veka) [Symbolism of figures in the literature of the Old Rus']. St. Petersburg, Aletejja Publ., 2000. 320 p. (In Russ.)

I9 Kirillin V.M. Skazanie o Tihvinskoj ikone Bogomateri “Odigitrija”. Literaturnaja istorija pamjatnika do XVII veka. Ego soderzhatel'naja specifika v svjazi s kul'turoj jepohi. Teksty [Tale of the Tichvin icon of Our Lady “Odigitrija.” A literary history of the work up to the $I 7^{\text {th }}$ century. Its contextual specificity and relations with a cultural epoch. Texts], IMLI RAN, OIDR. Moscow, Jazyki slavjanskoj kul'tury Publ., 2007.307 p., [9] 1., il. (In Russ.) Konjavskaja E. L. Drevnerusskie skazanija o chudotvornyh ikonah: osobennosti narrativa [Old Russian tales about miraculous icons: specific features of the narrative]. Narrativnye tradicii slavjanskih literatur: ot Srednevekov'ja k Novomu vremeni. Kjubileju chlena-korrespondenta RAN E.K. Romodanovskoj [Narrative traditions of Slavic literatures: from Middle Ages to Modernity. On the anniversary of correspondent member of RAS E.K. Romodanovskaya]. Novosibirsk, Omega Print Publ., 20I4, pp. 54-58. (In Russ.) Konjavskaja E.L. Problema obshhih mest v drevneslavjanskih literaturah (na materiale agiografii) [A problem of common places in Old Russian literatures (on the material of agiography)]. Ruthenica. NAN Ukraïni. İn-t istoriï Ukraïni [Ruthenica. NAS, Ukraine. Institute of the history of Ukraine], ed. V.M. Richka, O.P. Tolochko. Kiev, 2004, vol. 3 , pp. 80-92. (In Russ.) 
Kriza A. Letajushhie ikony Bogorodicy - pokroviteli russkogo gosudarstva [The flying icons of Our Lady - the patrons of the Russian state]. Rol' gosudarstva v istoricheskom razvitii Rossii [The role of the state in the historical development of Russia], ed. Szvák Gyula. Budapest, Russica Pannonicana Publ., 20II, pp. IOO-I2O. (In Russ.) Lavrovskij N.L. Povest' o chudotvornom obraze Bogorodicy, nahodivshemsja v Vydropuske [A tale of the miraculous image of Our Lady in Vydropusk]. Letopisi russkoj literatury i drevnosti [Chronicles of Russian literature]. Moscow, I862, part 3, pp. I9-28. (In Russ.)

Leonid, arhim. Skazanija i povesti o svjatyh chudotvornyh ikonah [Tales and tales about saint miraculous icons]. Russkij arhiv [Russian archive]. Moscow, I88I, book II (I), pp. 5-16. (In Russ.)

Malov E. Kazanskij Bogorodickij devichij monastyr': Istorija i sovremennoe ego sostojanie [Kazansky convent: history and modern state]. Kazan', I879. I42, XXI p. (In Russ.) Nemtinova V.V. Obraz Kazanskoj Bogomateri poslednej chetverti XVI veka iz sobranija Gosudarstvennogo muzeja izobrazitel'nyh iskusstv Respubliki Tatarstan: K istorii otkrytija i restavracii odnogo iz pervyh spiskov javlennoj chudotvornoj ikony [The image of Our Lady of Kazan' of the last quarter of the $16^{\text {th }}$ century from the collection of the State Museum of Fine Arts of the Republic of Tatarstan: to the history of discovery and restoration of one of the first copies of the miraculous icons]. Chudotvornyj Kazanskij obraz Bogorodicy v sud'bah Rossii i mirovoj civilizacii. Sbornik materialov Mezhdunarodnoj nauchno-prakticheskoj konferencii: Kazan', I9-2I ijulja 2016 g. [The Miracolous image of Our Lady of Kazan' in the world. Collection of conference papers]. Kazan', Centr innovacionnyh tehnologij Publ., 20I6, pp. I29-I3I. (In Russ.)

27 Patriarshaja, ili Nikonovskaja letopis' [Patriarch, or Nikon chronicle]. Polnoe sobranie russkih letopisej [Complete Collection of Russian chronicles]. Moscow, I965. Vol. II. VII, 254 p. (In Russ.)

28 Piskarevskij letopisec [Piskarevsky chronicle]. Polnoe sobranie russkih letopisej [Complete collection of Russian chronicles]. Moscow, I978. Vol. 34: Postnikovskij, Piskarevskij, Moskovskij i Bel'skij letopiscy [Postnikovsky, Piskarevsky, Moskovsky, and Belsky chronicles], pp. 3I-220. (In Russ.)

29 Pljuhanova M.B. "Kipenie sveta": Russkie Odigitrii v liturgicheskoj pojezii $i v$ istorii ["Kipenie sveta": Russian icons Odigitria in liturgic poetry and history]. St. Petersburg, Pushkinskij dom Publ., 20I6. 604 p., il.; 24 p. cv. vklejka. (In Russ.) 
30 Pozdeeva I.V., Turilov A.A. "Tetrati... pechatany v Kazane” [Notebooks... published in Kazan]. Drevnjaja Rus': Voprosy medievistiki. Moscow, 200I, no 2 (4), pp. 37-49. (In Russ.)

3 I Psaltyr's vossledovaniem [Psalm book]. NIOR RGB. Sobr. rukopisej Troice-Sergievoj lavry [Collection of manuscripts of Troize-Sergieva lavra] (f. 304.I). No 32I (848). 2-ja polovina XVI v. I3I4 l. (In Russ.)

32 Romanova A.A. Skazanie o ikone Bogomateri Okoveckoj (Rzhevskoj) [A tale of the icon of Our Lady Okoveckaya]. Clovar' knizhnikov i knizhnosti Drevnei Rusi [Glossary of Old Russian scribes and book culture]. St. Petersburg, 2004, vol.3, part 4, pp. 864-866. (In Russ.)

33 Rudi T.R. Topika russkih zhitij (voprosy tipologii) [Topoi of Russian lifewriting]. Russkaja agiografija: Issledovanija. Publikacii. Polemika [Russian agiography: studies, publications, polemics], eds. S.A. Semashko and T.R. Rudi. St. Petersburg, 2005, pp. 59-IOI. (In Russ.)

34 Skazanie o chudotvornoj Kazanskoj ikone Presvjatoj Bogorodicy: Rukopis' svjatejshego patriarha Germogena. S predisloviem akademika A.I. Sobolevskogo [A tale of the miraculous Icon of Our Lady of Kazan: Manuscript of his Holiness Patriarch Hermogene. With the introduction by academician A.I. Sobolevsky]. Moscow, I9I2. 8 p. (In Russ.)

35 Skazanie ob ikone Bogomateri Rimskoj. Perevod A. Ju. Nikiforovoj, predislovie A.M. Lidova [A tale of the icon of Our Lady of Rome. Trans. A. Yu. Nikiforova, introd. A.M. Lidov]. Relikvii v Vizantii i Drevnej Rusi [Relics in Byzantium and Old Rus'], ed. A.M. Lidov. Moscow, Progress-Tradicija Publ., 2006, pp. 225-237. (In Russ.)

36 Sobornik iz 7 I slova [Collection of 7I words]. Moscow, Pechatnyj dvor Publ., I647. 2. 879 1. (In Russ.)

37 Solodkin Ja. G. Piskarevskij letopisec [Piskarevsky chronicle]. Clovar' knizhnikov i knizhnosti Drevnei Rusi [Glossary of Old Russian scribes and book culture].

St. Petersburg, 1993, issue 3, part 2, pp. 269-274. (In Russ.)

38 Sofijskaja vtoraja letopis' [Sophiiskaya and chronicle]. Polnoe sobranie russkih letopisej [Complete collection of Russian chronicles]. St. Petersburg, I853. Vol. 6: Sofijskie letopisi [Sofiiskaya chronicles], pp. II9-276. (In Russ.)

39 Spasskij S., arhim. Polnyj mesjaceslov Vostoka [Complete Oriental menology]. Moscow, I876. Vol. 2: Svjatoj Vostok [Holy East]. XXII, 272, XII p. (In Russ.)

40 Spasskij F.G. Russkoe liturgicheskoe tvorchestvo [Russian liturgic work]. Moscow, Izdatel'skij Sovet RPC Publ., 2008. 544 p. (In Russ.)

4I Tvorenija svjatejshego Germogena Patriarha Moskovskogo i vseja Rusi. S prilozheniem china postavlenija patriarha [The works of his Holiness Patriarch Hermogene of Moscow. 
With amendments]. Moscow, I9I2. [IV], IIO p. (In Russ.)

Tolkovyj slovar' zhivogo velikorusskogo jazyka Vladimira Dalja [Explanatory dictionary of the Russian language by Vladimir Dal']. St. Petersburg, Moscow, M.O. Vol'f's Publ., I882, vol. 4. 704 p. (In Russ.)

Hazanova S.I. Piskarevskij letopisec: Proishozhdenie, istochniki, avtorstvo [Piskarevsky chronicle: origins, sources, authorship]. Moscow, Kvadriga Publ., 20I4, 220 p., I5 il. (In Russ.)

Celkova L.N. Motiv [Motif]. Vvedenie v literaturovedenie: Ucheb. Posobie [Introduction in literary studies], ed. L.V. Chernez. Moscow, Vyssh. shk. Publ., 2004, pp. 230-236. (In Russ.)

\section{Chugreeva N.N. Kazanskaja ikona Bozhiej Materi [Kazan Icon of Our Lady].}

Pravoslavnaja jenciklopedija [Orthodox encyclopedia]. Moscow, 2OI2, vol. XXIX, pp. I96-2I5. (In Russ.)

Chugreeva N.N. O javlennom v I579 godu v Kazane obraze Bogorodicy, rannih spiskah s nego i pozdnejshih vosproizvedenijah [On the apparition of the image of Our Lady of Kazan and its early and late copies]. Chudotvornyj Kazanskij obraz Bogorodicy v sud'bah Rossii i mirovoj civilizacii. Sbornik materialov [Miraculous image of Our Lady of Kazan in Russia and world civilization. Collection of papers], pp. I84-I86. (In Russ.) Chudotvornaja Kazanskaja ikona Bozhiej Materi. Zastupnica userdnaja roda hristianskogo [Miraculous Icon of Our Lady of Kazan, the miraculous Protector of the Christians], Eldashev and others., ed. Yu. V. Andreeva. Kazan', Centr innovacionnyh tehnologij Publ., 2012. 356, [3] p. (In Russ.)

48 Shmidt S.O. Skazanija ob afonskih monastyrjah v novgorodskoj rukopisi XVI veka [Tales of Afon monasteries and Novgorod chronicle of the $16^{\text {th }}$ century]. Drevnerusskaja literatura i ee svjazi s novym vremenem [Old Russian literature and its connections with modern time]. Moscow, I967, pp. 358-360. (In Russ.)

49 Ebbinghaus A. Die altrussischen Marienikonen Legenden. Berlin, I990. 290 p. (In German)

50 Kriza A. A középkori orosz képvédó irodalom. I rész. Bizánci forrasok, Kriza A. Drevnerusskie teksty $v$ zashchitu ikon [Old Russian texts in defense of icons]. Russica Pannonicana, Budapest, 20II. Part I: Vizantiiskoe nasledie [Byzantium legacy]. 324 p. (In Russ.)

5I $\quad$ Petri Lambecii... Commentariorum de aug Bibliotheca caesarea Vindobonensi. Liber 8... quo continetur catalogus manuscriptorum codicum graecorum historicorum ecclesiasticorum... Vindobonae [Wien]; Typis Matthei Cosmerovij, I679. [4] p., 788 col. (In Russ.) 